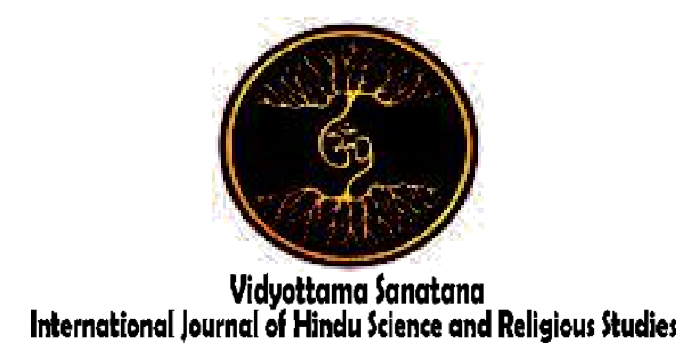

Vol. 2 No. 2 October 2018

\title{
Dharmasasananing Pandita In Hindu Diversity System In Bali
}

\author{
By: \\ I Ketut Sudarsana \\ Institut Hindu Dharma Negeri Denpasar \\ E-mail: sudarsana_mpu@gmail.com
}

Received: July 21, 2018

Accepted: September 29, 2018

Published: October 31, 2018

\begin{abstract}
Hindus feel disappointed and disgraced if one of their figures who should be a leader and purified does a disgraceful deed such as having an illegal wife, working as a middleman, slandering and so forth. In short, Hindus feel disappointed and disgraced if one of their figures who should be a leader and purified "deviates" from the ethical code of priesthood (dharmasasaning pandita). Just to remind again that when someone starts his priesthood, the ethical cod of priesthood (dharmasasananing pandita) should be used as the parameter of his identity as a holy person. In many Hindu literary works, the dharmasasananing pandita has been included. The reasons why a priest often 'deviates' from the ethical code of priesthood are as follows. From the internal dimension, the senior priest (nabe) is often used as a symbol, the impact of the symbolic capital "power" and the impact of uncontrollable sexual libido. The external dimension includes: the impact of external 'education', the impact of genealogical caste, and impact of the market ideology. The implications on a priest are as follows: he will become a what is called patita, he will die young, he will go to hell, and it is believed that, when he is reincarnated, he will not become a human being any longer. The implications on society are as follows: conflicts cannot be avoided, more and more people are getting poor, religious conversion cannot be avoided, and society will become psychologically depressed.
\end{abstract}

Keywords: dharmasasananing pandita, Hindu diversity system in Bali

\section{Introduction}

A Bali Hindu who has been ordained (di-dwijati) as a priest should do his obligations as a holy man; he should follow the principles/regulations already determined as a priest; he should avoid any disgraceful deed which may degrade his status as a respected holy man. In addition, he cannot freely do any activity which is profit oriented. He should dedicate the knowledge 
he has to maintain his 'status' as a priest, depending on his ability. He should not collect material and other worldly attributes; he should be a model to his followers, most of whom are less "lucky". When worshippers do not have any model or example from political leaders and bureaucrats, the priest should be used as a model; however, the fact shows a different thing.

The priest's religious knowledge is only a "discourse". Several cases have appeared recently, in which several priests are reported to 'deviate' from the ethical code of priesthood (dharmasasananing pandita). They should not have made such deviations, as when they are ordained as priests, their knowledge is considered adequate. In the past, almost there were no complaints about the relationship between priests and the senior priests (nabe). The white uniforms worn by priests should be accompanied with good ethics. However, there have been rumors that there are several priests who still undertake businesses, work as merchants, and are still bound to worldly material. There have also been rumors that there are priests whose life style is profane, have illegal wives, and are involved in politics. There have also been rumors that there are priests who degrade the "status" of their followers.

Hindus feel disappointed and disgraceful if their figures that are supposed to be models and purified "deviate" from the ethical code of priesthood (dharmasasananing pandita). The globalization era has changed the tradition of being ordained as priests in Bali into the tradition which is full of rituals, meaning that financial factor also determines whether someone will become a priest or not. It needs a lot of money if someone would like to become a priest in Bali. Therefore, when he is supposed to perform a ritual, he sets a fare. The negative impact is that there will be a competition among the priests; as a result, they will deviate from the ethical code of priesthood. Many priests will not be faithful to their daily and temporal obligations. The priests who are purified by their followers are obliged to faithful to the ethical cod of priesthood. They should give spiritual guidance sincerely based on yadnya (sacrificial principle). They should not be careless in maintaining their behavior (tan ptyatna rumakseng sila). In short, when someone starts priesthood, he should use the ethical code (dharmasasananing pandita) as the parameter, and should be a model for his followers.

Based on the background above, the problems formulated in the present study are as follows. What is the ethical code (dharmasasananing pandita) in the Hindu diversity system in Bali like? What causes the priests to deviate from the ethical code of priesthood in the Hindu diversity system in Bali? What is the implication of deviating from the ethical code of priesthood (dharmasasananing pandita) in the Hindu diversity system in Bali?

\section{Result}

\section{The Ethical Code of Priesthood (Dharmasasananing Pandita)}

In the Sanskrit dictionary, it is stated that the word dharma means institution, tradition, habit, regulation, good morality, good job, truth, law and justice (Astra et al, 2001: 223). According to Zoetmulder and Robson, the word dharma means what is determined and affirmed, law, habit, the way of behaving determined by tradition, obligation, justice, good deed, kindness, politeness, religion, good job, clear form or condition, born characteristic, basic nature (essential), specific nature, merit and feature (1997: 197). In line with what is defined above, the word dharma means every movement of thought, what is said, and behavior leading to what is true, namely, the way to God.

The word dharmasasana in the Sanskrit Dictionary means the holy code of dharma (Zoetmulder and Robson, 1997: 200). According to Yendra (2008: 8), the word sasana means behavior or obligation. In the Indonesian language, the word dharmasasana is identical with good conduct (tata susila), the basis of kindness 
which is used as guidance to human life; the obligation which should be fulfilled as the community members. The word ning means what is performed from and by (Arwati, 2008: 3).

In the Sanskrit Dictionary, it is stated that a priest means someone who is educated, clever, or a wise scholar (Astra et al, 2001: 241). According to Wiana (2002: 85), the spiritual actualization of a priest is what is called jnana agni; the priest should be able to activate his holiness by igniting the fire of knowledge (jnana agni). In Manusmerti Book XII. 108, it is stated that a priest, or what is referred to as sang sista, is an expert in Vedic holy habits. In general, a priest in Bali is free from his societal obligations such as the activities which should be voluntarily performed for the village and banjar (the smallest brotherhood after the traditional village) and other physical and societal activities.

The ethical code of priesthood (dharmasasananing pandita) is not only related to the actualization of good behavior (tingkah laku kedharman) but also to the obligations as determined by religious, spiritual, and holy regulations, traditions, daily activities, routines, and periodical activities which are generally and specifically performed by the Hindu priests such as pedanda, rsi, bujangga, pandita mpu, pandita dukuh, sire empu and bagawan) which do not contradict the Holy Book Veda and other Hindu literary works.

\section{Hindu Diversity System in Bali}

Shrode (Syani, 2007: 123) defines a system as a set of interrelated parts, working independently and jointly, in pursuit of common objectives of the whole within a complex environment.

A system is a set of the things which are united into a whole as they are interrelated to and interdependent on one another; a system is a collection of objects, ideas, rules, axioms and so forth) which are arranged in an order (subordination, or conclusion, generality and so forth) which are coherent in accordance with a rational principle (or a plan, or a scheme, or a method) or which can be understood. A system is a group of principles or operating methods which can possibly be achieved or clarified (as in the system of classification) (Bagus, 2005: 1015).

According to Syani (2007: 127), common people usually define a system as the technical manner of doing something; however, sociologically, actually a system means a collection of various elements (components) which are dependent on one another as a whole. Amirin states that a system is an organized collection of concepts; it is a collection of principle concepts, doctrines, laws and so forth which contribute to a logical unity and is well known as the content of a particular philosophical thought, religion or the form of a particular government (2003: 3).

A Hindu diversity system in Bali refers to a manner of performing something such as performing habits, traditions and customs, belief, attitude which are organized in such a way that it is related to the culture of Hindu Bali 'specific' identity. The specific features of such a 'system', according to Gunadha (2008: 13), include (1) the fact that it is based on Siwa-Budha tattwa (the philosophy of Siwa-Budha), (2) being related to what is called kahyanangan tiga (the three main temples in a traditional village), (3) performing what is called panca mahayadnya, (4) using upakara (offerings) based on the Hindu holy books and palm leaf manuscripts available in Bali, (5) being featured by the family temple in the family environment, and (6) using the Hindu ethics as guidance to behaving. As a general picture, if related to 'institutionalization', a priest is obliged to use accessories such as siwapakarana, mabawa/maketu or other attributes/dress when leading a ceremony as determined in the Hindu literary works. Before he leads a ceremony, he should prepares holy water with what is called vedaparikrama, which is acknowledged and followed in the Hindu diversity system in Bali, and is based on the regulations which do not contradict the essence of the Holy 
Book Veda. What is outside what is specified above is not included in the Hindu diversity system in Bali.

\section{The Hindu Ethics}

The teaching of Hindu ethics has been available since the Vedic era. New changes have taken place in ethics as far as the yadnya (sacrificial ceremony) is concerned. The word ethics meaning 'repenting' in the Holy Book Rgveda during the Yajurvedic era has become sin confession (Phalgunadi, 2010: 22). Etymologically, the word ethics is derived from the word ethos. The word 'ethos', in its singular form, means a common residence, habit, moral tradition, feeling, and a way of thinking. In its plural form, the words ta etha means customs and tradition. In philosophy, the term ethics means a science which is concerned with what is commonly done or a science which is concerned with customs and traditions (Sadulloh, 2006: 40, Mufid, 2009: 173). In Kamus Lengkap Bahasa Indonesia (the complete Indonesian Dictionary), the word ethics means behavior and etiquette (Novia, t.t: 123). Thus, the word ethics is a branch of moral philosophy which is concerned with what is done by human beings. Ethics is the philosophy which is concerned with human behavior (Sadulloh, 2006: 41).

According to Runes, ethics (Sadulloh, 2006: 40) means: that study or discipline which is concerned itself with judgment of approval or disapproval, judgments as to rightness or wrongness, goodness or badness, virtue or vice, desirability or wisdom of action, end objects, or state of affairs.

According to the Britanica Encyclopedia, ethics is the systematic study of the nature of values, concept, 'good', 'bad' 'oughth', 'right', 'wrong', etc, and of the general principles which justify us in applying them to anything, also called 'moral philosophy'.

According to Mufid, ethics can be differentiated into three main definitions; they are: a science which is concerned with what are good and moral obligations; a collection of principles or values which is related to morality and the wrong and right values which are adhered to by a group of people or society. Furthermore, ethics can also be defined as values or norms which are used as guidance by someone or a group of people to organize their behavior (2009: 173). In short, ethics is a discipline (a branch of philosophy) which learns what is good and what is bad and their justifications which are adhered to by human beings (Supriyadi, 2000: 6).

Hindu ethics, according to Sumadi (2011: 3), is the norms which regulate good and truthful behaviors based on Hinduism. What is good and truthful, based on the Hindu teaching, may be external (tri hita kharana) and internal (oneself). Another word for Hindu ethics is susila; actually, it is a form of self control to Hindus in their social intercourse so that the relationship between them and their environment will be in harmony. Whether someone's ethics is good or bad depends on the situation and condition. Widnya (2011: 6) states that Hindu ethics refers to the values which refer to the Hindu teaching which is daily put into practice by the Hindus and others who believe that they are different. Furthermore, Widnya states that the values of what is good and what is not good, and what may be done and what may not be done have already been determined in the Hindu teaching.

Pandit states that the Hindu ethics is created for the need to harmonize individual desires, emotion and ambition. In this way, a harmonious life is created on earth; the objective is to make individuals aware of self awareness (2005: 135). Being recognized or not, ethics has been known since the first human being was created on earth. Ethics is the most important thing in human life. If what is done by someone deviates from ethics, then his life will be useless and lead to various implications.

\section{Professionalism/Duties/Obligations /Role Played by a Priest}

A priest has daily duties and obligations referred to as arcane or ngarcana Sang Hyang Widhi Wasa and BhataraBhatari (Worshipping Almighty God, Gods, 
and Goddesses). He should study Veda, tattwa and tutur-tutur (stories). He should also be interested in teaching holiness, spirituality, and religious things, and this is what is referred to as adhypaka. He should also study diligently by himself; he should repeat what is provided by his senior priest, which is called swadhyaya. As well, he should also meditate upon Brahma or the greatness of Ida Sanghyng Widhi (Almighty God) and the essence what is worshipped (Sastra, 2005: 46).

In accordance with what was decided in Mahasabha II PHDI/1968 (Summit II held by the Highest Administrative Council of Hindu Religion/1968), the duty and obligation of a priest during his life are creating prosperity physically and spiritually and performing upacara yadnya (Sacrificial Rituals). He is expected to be able to lead pemangku/pinandita (priests who do not have to be ordained). He should also actively take part in any meeting or discussion which is intended to establish religious teachings. $\mathrm{He}$ should also give dharma upadesa (enlightenment) to his followers and never forget to visit holy places (matirthayatra).

In Sarasamuccaya sloka 40, it is stated that a priest has four duties/roles; therefore, he is called:

a. Sang Satyavadi, meaning that he should always speak truthfully and honestly. Therefore, he should be what is called satya hredaya (being faithful to his inner heart), satya mitra (being faithful to his friends), satya laksana (being faithful to what is done), satya wacana (keeping his words), and satya semaya (keeping his promise). What is meant by the truth is that which is based on the Hindu literary works rather than on his personal opinion in order to maintain his pseudo power.

b. Sang Apta, meaning that he should always be trusted and never tell a lie; he should always do what is true; as well, he should always be honest. He is referred to be apta if he is able to give response to what is requested by his followers; he can lead his followers; he should be able to direct his followers; and he should lead to physical and spiritual prosperity. In addition, he should also be able to direct and supervise his followers; he should also be able to solve any problem which is related to spirituality, precious days, and sacrificial rituals; in addition, he should also protect his followers.

c. Sang Patirtan, meaning that he should be a place where people may go to purify themselves physically and spiritually; he should be a place where the holy water of life (tirtha amertha) can be obtained. He has the authority to create (ngarga) what are called tirtha penglukatan, pebersihan/prayascita and so forth. In this case, he is required to be mentally prepared; what is thought about, what is said, and what is done should be sacred.

d. $\quad$ Sang Panadahan Upadesa, meaning that as a priest he should be a good leader/teacher in his physical environment and social environment; he should be able to develop moral education and Hindu mentality. In short, he should be able to give enlightenment using simple language rather complicated language. In addition, he should also behave simply.

Apart from what was mentioned above, in accordance with Bhagavadgita IX 33, a priest should be:

Kim punar brahmanang punya bhakta rajasayas tatha

Anityam asukham lokam imam prapya bhajaswa man

Translation:

The holy Brahmin or priest, after being in the temporary world of sadness, you should worship Me (Maswinara, 2007: 322).

Furthermore, in Bhagavad Gita IX.34, it is stated that:

Man-mana bhawa mad-bhkto madyaji mam namaskuru

Mam ewaisyai yukrwaiwam atmanam mat-parayanah

Translation:

Concentrate your mind on $\mathrm{Me}$; be devoted to Me; worship and be humble to $\mathrm{Me}$; and by disciplining yourself and making $\mathrm{Me}$ as your 
objective, you will reach $\mathrm{Me}$ (Maswinara, 2007: 322).

From what was described above, it can be concluded that the most important thing in the priesthood teaching is total submission to Hyang Widhi Wasa (Almighty God). The whole life will transform and have the 'vision' that God is everywhere. All sadness and unhappiness will disappear and mind will become united with the divine awareness. In accordance with Manava Dharmasastra Book, a priest's obligations can be formulated into three parts as follows. (1) Studying Veda, teaching Veda, and performing Sacrificial Rituals (upacara yadnya) and receiving donations (dana punia). (2) Teaching, studying and making sacrifices for himself, sacrificing for others, giving what is called daksina, and receiving it. (3) Following ten laws of life; they are being established in his objectives and duties, easily apologizing others, controlling himself, being honest, always purifying himself, controlling his desires, being strong in his faith, being knowledgeable of the main soul, always referring to what is true and never being angry. Having dialogues using logical arguments to express what is true is not classified as being angry.

\section{The Factors Leading to "Deviations" from the Ethical Code of Priesthood (Dharmasasananing Pandita)}

When implementing the ethical code of priesthood (dharmasasananing pandita), it is impossible for a priest not to make any mistake or 'deviation', making what is done is far from what is called sasana walaka. It is not easy when having decided to be a priest. As a public servant, he should sincerely do his obligations with full responsibilities. However, 'deviations' cannot be avoided. Some factors which are responsible for this are classified as internal dimension such as his senior priest (nabe) is only used as a symbol. After being a priest, assuming that he is everything, he forgets the ethical code of priesthood which is highly complex, especially the relationship between himself as a junior priest (nanak) and his senior priest (nabe), giving an impression that his senior priest (nabe) is only a symbol. He neglects what is instructed by his senior priest, although he should keep the concept maala-ayu tunggal (the senior priest's suffering is the junior priest's and vice versa).

The impact of the symbolic capital "power"; a priest in the Bali Hindu is like a 'visible god'. What he instructs, as a human, is followed by his followers, although it is not by all means true. His followers are becoming reluctant; they are too afraid of making "sins"; as a result, he may use his capital of power. Finally, 'deviations' cannot be avoided. His spirituality is still inadequate; and there are still many priests who differentiate his followers when they have a sacrificial ritual (upacara yadnya). As a consequence, the followers 'sisya' coming from the lower class are marginalized. The concept wedanta teaches that a human being is equal to another; they are brothers (wasudewa kutumbhakam), coming from the same source (Brahman). The sexual libido is uncontrollable. The high sexual desire to satisfy the sexual libido cannot be controlled. Finally, the priest becomes what is called 'kama wisaya', meaning that he has an illegal wife.

Externally, the factors which cause a priest to make deviations from the ethical code of priesthood (dharmasasananing pandita) are the external teachings. He considers that any ritual in which many types of offerings (banten) are needed burden the Hindu worshippers. Furthermore, he states that banten is not in accordance with the current era development. There is a group of Hindu worshippers in Bali who do not use banten at all. There is a priest who intentionally modifies what is called plutuk banten as he likes; in addition, banten is not used properly any longer. There is also a priest who is ordained by his senior priest (nabe) based on the teaching which is adopted from outside in which the junior priest is requested to kiss the senior priest's feet, although the feet of such a nabe's nabe have not never been kissed. 
The impact of belonging to the "genealogical" caste; a priest who belongs to "brahmangkura caste" considers that the only his group who can perform a public ritual such as in the government, the traditional village and other big temples in Bali. The priest who belongs to the other clans does not have the authority to perform such a ritual. Then, there is the impact of the market ideology. It is possible that a priest has material more than needed. It is possible that such material is acquired without paying attention to the condition of his consumers. The objective why he wants to be ordained is collecting wealth using his high level of education and 'multiple positions.

\section{Implication of "Deviations from the Ethical Code of Priesthood (Dharmasasananing Pandita)}

The implication of the deviations made by a priest from the ethical code of priesthood (dharmasasananing pandita) is that he will become what is called patita (his status of priesthood is eliminated). If he has become a patita, he does not have the authority to perform his priesthood duties, meaning that he becomes what is called walaka again. Nobody may ordain a patita. Nobody may ordain him for the second time. A priest who ordains someone for the second time will soon die and will frequently be sick; he will go to hell "kalebok ring kawah tambragohmuka". There are many hells where the priest who deviates from the ethical code (dharmasasanaing priesthood) may go, depending on the deviations he has made. It is believed that he will reincarnated into a non human being; he will possible be born as an animal or strange creature whose name cannot be mentioned. The impacts on society are (a) leading to an extended and open conflict; (b) causing people to become poorer, if the priest forces people to perform luxurious rituals from time to time which only benefit the priest and his colleagues. The people are already poor and then they are made to be getting poorer.

Too many ceremonies performed in Bali have caused many people to get poor. In one year, there are tens ceremonies which have caused the Balinese people to spend a lot of money. In fact, they are poor and their income is inadequate. The three factors which contribute to the theory of the cycle of poverty (vicious circle of poverty) can be described as follows.

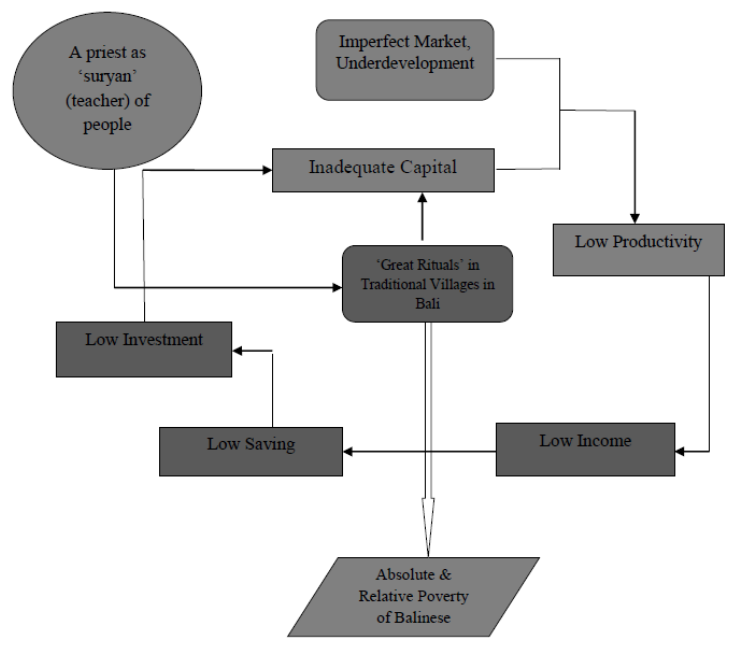

Source: Modified Nurkse (in Subandi, 2014). There are many things which contribute to the vicious circle of poverty in Bali. The above figure refers to the concept of logical way of thinking proposed by Nurke (Subandi, 2014) reflecting underdevelopment, imperfect market, and inadequate capital causing productivity to be low. The low productivity causes the income earned to be low. The low income causes the saving and investment to be low. The low investment causes underdevelopment. The request made by the priest that his followers perform great ceremonies in every traditional village in Bali is also responsible for the underdevelopment, meaning that it also contributes to absolute and relative poverty among the Hindus in Bali. (c) "Religious conversion" takes place in its wide definition (not in accordance with the system of the Hindu Bali belief). If such a religious practice is regarded as not being able to be used as guidance to the objective of life, then its followers will certainly leave the diversity system inherited from generation to generation. The material-oriented priest in Bali will tend to make his followers to be gradually unhappy and then religious 
conversation cannot be avoided. In addition, people are getting psychologically depressed in responding to the globalized life; the mental conflict cannot be avoided, and more and more Balinese people will become mad.

\section{Conclusion}

The ethical code of priesthood (dharmasasananing pandita) includes the duties and responsibilities of a priest which he should be responsible to society and Almighty God (Sanghyang Widhi Wasa). Various Hindu literary sources explicitly contain it such as Bhagawadgita, Sarasamuscaya, Manawadharasastra, Wrtisasana, Siwasasana, Silakramaning Aguron-guron,Slokantara, Agastyaparwa, Tattwa Brata, Wasita Tattwa, Weda Parikrama/ARgha Patra and so forth.

The education which has been acquired by the priests has not significantly contributed to their etiquette. Even the highly educated priests have made "deviations" from ethical code of priesthood (dharmasasananing pandita). Such priests should not have made such deviations. They are the symbol of the Bali Hindus; however, they still recite puja amitaba.

Not many priests understand the knowledge of "aji kaweruhan" (the science of spirituality), although they absolutely know it if they want to do what they are supposed to do. There are still some priests who practice black magic (aji pengleakan). Some still perform what is called patiwangi ritual (a ritual through which someone's caste 'wangi' is eliminated. Actually, this contradicts the Hindu teaching and was deleted by the Bali Government in 1951. If the patiwangi ritual was not performed, then such a group of priests would not be willing to perform the wedding ceremony. The reason is that the bride and bridegroom belong to different castes. Recently there have been a number of legal cases happening to several priests in Bali. The situation and condition which are developing in society have been responsible for this. As an illustration, some priests have been summoned by court as witnesses.
In short, attempts are necessarily made to pay attention to the existence of priests so that they will do their best to enhance and strengthen the ethical code of priesthood (dharmasasananing pandita) when they give their services to the Hindus. The priests play an important role in improving the quality life of the Hindus; as a result, if it is a superior program of the competent parties, the self identity and dynamism of the Hindu diversity system will be more adaptive in the future.

\section{References}

Abdullah, Irwan dkk. 2008. Dialektika Teks Suci Agama, Strukturasi Makna Agama dalam Kehidupan Masyarakat. Yogyakarta: Sekolah Pascasarjana Universitas Gajah Mada dan Pustaka Pelajar.

Ahmadi, Abu. 2009. Psikologi Sosial. Jakarta: Rineka Cipta

Amirin, Tatang M. 2003. Pokok-Pokok Teori Sistem. Jakarta: Raja Grafindo Persada.

Anandamurti, Shrii Shrii. 2008. Pegetahuan Spritual dalam Kitab Veda. Jakarta: Ananda Marga Indonesia.

Astra, I Gede Semadi dkk. 2001. Kamus Sanskerta Indonesia. Denpasar: Proyek Peningkatan Mutu Pendidikan Pemerintah Daerah Tingkat I Bali.

Atmadja, Nengah Bawa. 2010. Komodifikasi Tubuh Perempuan, Joged "Ngebor Bali”. Denpasar: Pustaka Larasan.

Ali, Sayuti. 2002. Metodologi Penelitian Agama Pendekatan Teori dan Praktek. Jakarta: Raja Grafindo Persada.

Bagus, Lorens. 2005. Kamus Filsafat. Jakarta: Gramedia Pustaka Utama.

Bertens, K. 2002. Etika. Jakarta: Gramedia Pustaka Utama.

Bungin, Burhan (ed.). 2003. Analisis Data Penelitian Kualitatif. Jakarta: Raja Grafindo Persada.

Daksa, Acharya Paramananda Muni. 2009. Siddhashram Ratu Bagus, dari Informasi Menuju Transformasi. 
Denpasar: Gue Deliquantum Volor Alisis Acil U dan Udayana Universitas Press.

Endraswara, Suwardi. 2003. Metodologi

Penelitian Kebudayaan. Yogyakarta:

Gajah Mada Universitas Press.

Gunadha, Ida Bagus, 2008. "Identitas

Manusia Bali: Perspektif Adat,

Agama, dan Budaya". dalam

Makalah Kongres Kebudayaan Bali

14-16 Juni 2008 di Denpasar.

Hardiman, F. Budi. 1993. Мепијu

Masyarakat Komunikatif. Ilmu,

Masayarakat, Politik, dan

Posmodernisme Menurut Jurgen

Habermas. Yogyakarta: Kanisius.

Howard, Roy J. 2000. Three Faces Of

Hermeneutics: An Introduction to

Current Theories of Understanding.

Pengantar Atas Teori-Teori

Pemahaman Kontemporer:

Hermeneutik; Wacana Analitik,

Psikososial dan Ontologis. (Terj.

Kusmana dan M.S. Nasrullah).

Bandung: Nuansa.

Hooykaas. C. 1971. Stuti and Stava

(Bauddha, Saiva and Vaisnava Of

Balinese Priest). Amsterdam: Nort

Holland Publising Company.

Jalaludiin. 2010. Psikologi Agama. Jakarta:

Raja Grafindo Persada.

Leatherman, Janie dkk., 2004. Memutuskan

Siklus Kekerasan Pencegahan

Konflik dalam Krisis Intranegara.

(Terj. Muba Simanihuruk dan

Subhilhar. Yogyakarta: Gajah Mada

Universitas Press.

Kadjeng, I Nyoman, dkk.1997. Sarasamuccaya. Surabaya: Paramita.

Kaelan. 2005. Metode Penelitian Kualitatif

Bidang Filsafat. Yogyakarta:

Paradigma.

Maryaeni. 2005. Metode Penelitian

Kebudayaan. Jakarta. Bumi Aksara.

Maswinara, I Wayan (Penerjemah). 2000.

Bhagavad Gita. Surabaya: Paramita.

Moeleong, Lexy J, 2001. Metodologi

Penelitian Kualitatif. Bandung:

Remaja Rodaskarya.
Mufid, Muhamad. 2009. Etika dan Filsafat Komunikasi. Jakarta: Prenada Media Group.

Muzir, Inyiak Ridwan. 2008. Hermeneutik Filosofis Hans-Georg Gadamer.

Novia, Windy. T.t. Kamus Lengkap Bahasa Indonesia. Surabaya: Kashiko.

Pals, Daniel. 2001. Seven Theoris Of Religion. (Terj. Ali Noer Zaman).Yogyakarta: Qalam.

Pandit, Bansi. 2001. The Hindu Mind. New Delhi: New Age Books.

.Pandit, Bansi. 2005. The Hindu Mind. Pemikiran Hindu (Terj. IGA Dewi Paramitha). Surabaya: Paramita.

Poerwadarminta, W.J.S. 1976. Kamus Umum Bahasa Indonesia. Jakarta: Balai Pustaka.

Pendit, I Nyoman S. 1986. Bhagavadgita. Jakarta: Dharma Nusantara.

Pigeaud,Theodore G. TH. 1980. Literatur of Java Volume IV Supplement. Leiden Universitas Press.

Priyatna, Haris. 2013. Kamus Sosiologi, Deskriptif dan Mudah Dipahami. Bandung: Nuansa Cendekia.

Pudja, I Gde dan Tjok Rai Sudharta. 2002. Manawa Dharmasastra. Wedasmrti Compedium Hukum Hindu. Jakarta: Nursatama Lestari.

Polomo, Margareth Mead. 2000. Sosiologi Kontemporer. Jakarta: PT Raja Grafindo.

Priyono, B. Herry. 2002. Anthony Giddens Suatu Pengantar. Jakarta: Kepustakaan Populer Gramedia (KPG).

Radhakrishnan, S. 2003. Religion And Society. (Terj. Tim Penerjemahan Program Magister Ilmu Agama dan Kebudayaan Universitas Hindu Indonesia: Indiani dan Inten Mayuni). Denpasar: Widya Dharma.

Ritzer, George dan Douglas J. Goodman. 2005. Teori Sosiologi Modern. Jakarta: Prenada Media.

Saebani, Beni Ahmad. 2007. Sosiologi Agama. Bandung: Refika Aditama 
Sarma, PT. Kisanlal, 2007. Mengapa? Tradisi dan Upacara Agama. Surabaya: Paramita.

Subandi, 2014. Ekonomi Pembangunan. Bandung: Alpabeta.

Spradley. James P. 1997. The Etnografic Interviu. Metode Etnografi. (Terj. Misbah Zulfa Elisabeth). Yogyakarta: Tiara Wacana.

Singarimbun, Masri dan Sofian Effendi (ed.). 1987. Metodologi Penelitian Survai. Jakarta: LP3S.

Soetriono dan SRDm Rita Hanafie. 2007. Filsafat Ilmu dan Metodologi Penelitian. Yogyakarta: andi.

Sudharta, Tjok. 2003. Slokantara, Untaian Ajaran Etika, Teks, Terjemahan, dan Ulasan. Surabaya: Paramita

Sukarsa, Made. 2009. Biasa Upacara Manusia Bali. Denpasar: Arti Foundantion.

Supriyadi, Gering. 2000. Etika Birokrasi. Jakarta: Lembaga Administrasi
Negara Republik Indonesia (LAN$\mathrm{RI})$.

Syani, Abdul. 2007. Sosiologi, Skematika, Teori dan Terapan. Jakarta: Bumi Aksara.

Tim Penyusun. 1991. Kamus Besar Bahasa Indonesia. Jakarta: Balai Pustaka.

Wiana, I Ketut. 2002. Veda Vakya Tuntunan Praktis Memahami Veda, Jilid Pertama. Denpasar: Pustaka Bali Post.

Wilkes, Chris, Richar Harker dan Cheelen Mahar (ed.). T.t. (Habitus x Modal) + Ranah $=$ Praktik, Pengantar Paling Konprehensif kepada Pierre Bourdieu. Yogyakarta: Jala Sutra.

Wirawan. 2013. Kepemimpin, Teori, Psikologi, Prilaku Organisasi, Aplikasi dan Penelitian. Jakarta: Raja Grafindo Persada.

Zoetmulder, P.J. dan Robson. 1977. Kamus Jawa-Kuno-Indonesia. Jakarta: Gramedia Pustaka Utama. 